\title{
Reactions of diethyl 2-(ethoxymethylene)malonate with 2-cyanoacetanilides: unexpected transfer of the ethoxymethylene moiety
}

\author{
Valeriya P. Tkachova, ${ }^{a}$ Nikolay Yu. Gorobets, ${ }^{\text {b }}$ Roman P. Tkachov, \\ Oleksandr D. Dyachenko, ${ }^{a}$ Eduard B. Rusanov ${ }^{c}$ and Vladimir D. Dyachenko ${ }^{a}$ \\ ${ }^{a}$ Taras Shevchenko Luhansk National University, Oboronna Str. 2, Luhansk 91011, Ukraine \\ ${ }^{b}$ Department of Chemistry of Heterocyclic Compounds, SSI 'Institute for Single Crystals', \\ National Academy of Science of Ukraine, Lenin Ave 60, Kharkiv 61001, Ukraine \\ ${ }^{c}$ Institute of Organic Chemistry of NAS of Ukraine, Murmanska 5, 02094 Kyiv, Ukraine \\ E-mail:gorobets@isc.kharkov.com;umaxous@gmail.com
}

\begin{abstract}
A sodium ethoxide catalyzed reaction of $N$-substituted cyanoacetanilides 1a-f with diethyl 2-(ethoxymethylene)malonate 2 unexpectedly leads to the corresponding 2-amino-5-cyano-6oxo-N,1-diaryl-1,6-dihydropyridine-3-carboxamides 3a-f, while the expected 5-cyano-2hydroxy-6-oxo-1-aryl-1,6-dihydropyridine-3-carboxylates 4a-f were observed only as minor products.
\end{abstract}

Keywords: Cyanoacetanilides, 2-pyridone derivatives, ethoxymethylene derivatives, diethyl 2-(ethoxymethylene)malonate

\section{Introduction}

The synthesis of 2-pyridone derivatives is of a continued interest in the field of heterocyclic chemistry. Several topical reviews have appeared in the literature over the last years about the synthesis of the 2-pyridone ring. ${ }^{1}$ These heterocycles attracted attention because of their applications as bioactive compounds for example as a promising class of HIV-1 non-nucleoside reverse transcriptase inhibitors (NNRTIs), ${ }^{2}$ as antibacterial, ${ }^{3}$ antifungal ${ }^{4}$ and cardiotonic agents. ${ }^{5}$ Moreover, such derivatives have recently become important due to their structural similarity to nucleosides. ${ }^{6}$ Also, 2-pyridones were used as ligands for the late $3 \mathrm{~d}$-metals. ${ }^{7}$ Thus, the development of novel methods for the synthesis of the 2-pyridone ring is of topical interest.

Our efforts in this area are focused on the synthetic routes where the 2-pyridone ring is assembled from a C-1 synthon and two methylene active components. ${ }^{8}$ Application of $N$-substituted cyanoacetamides as $\mathrm{CH}$-acids ${ }^{9}$ in such schemes allows introduction of an 
additional diversity point into the final 2-pyridone molecule via the amide group ${ }^{10}$ or, depending on the reaction conditions, leads to $N 1$-substituted 3-cyano-2-pyridones. ${ }^{11}$

In this work we aimed to investigate a novel interaction of $N$-substituted cyanoacetamides 1a-f with diethyl 2-(ethoxymethylene)malonate ${ }^{12}$ (DEEMM) 2.

\section{Results and Discussion}

Reactions of $N$-substituted cyanoacetamides 1a-f with DEEMM 2 in EtOH in the presence of 1.0 equiv of EtONa at room temperature resulted in the isolation of diaryl derivatives 3a-f as major products instead of the expected ethyl carboxylates 4a-f (Scheme 1). The compounds 3a-f were isolated upon filtration in moderate to good yields after recrystallization (Table 1, Method A), however, the formation of the expected products $4 \mathbf{a}-\mathbf{f}$ was also detected by LC/MS of the crude products 3a-f.

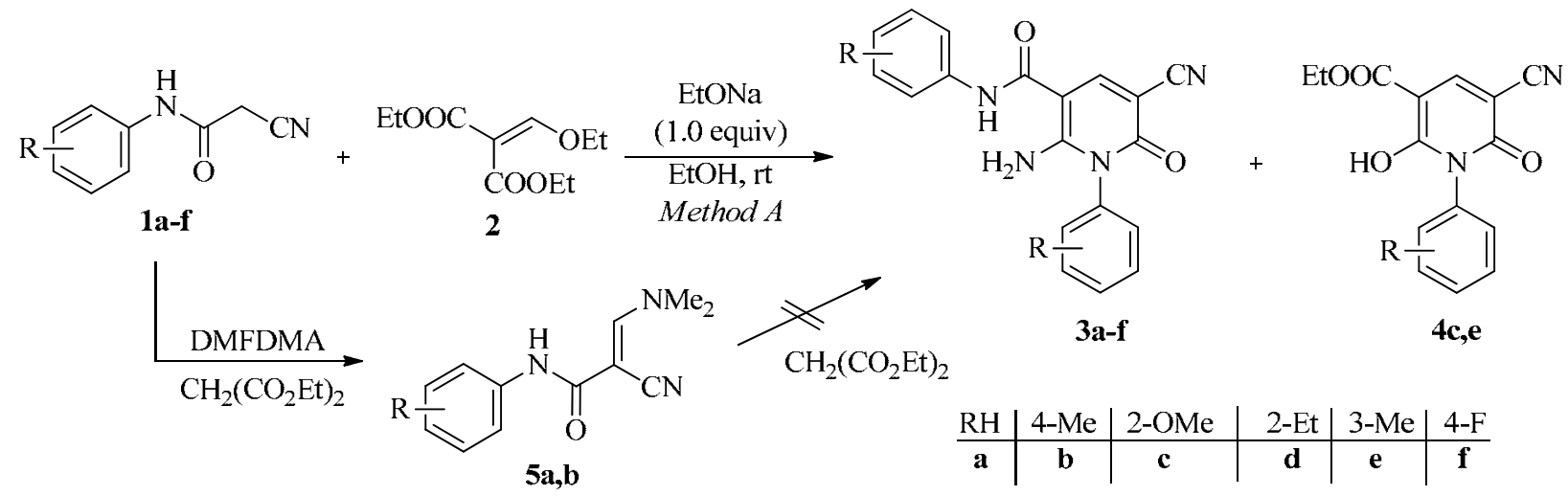

\section{Scheme 1}

Table 1. Isolated yields of the synthesized compounds 3a-f, $4 \mathbf{c}, \mathbf{e}$ and $\mathbf{6 c}$

\begin{tabular}{lll}
\hline Product & \multicolumn{1}{c}{ R } & $\begin{array}{c}\text { Isolated yields, \% } \\
\text { Method A (B) }\end{array}$ \\
\hline 3a & H & $40(93)$ \\
3b & $4-\mathrm{Me}$ & $71(91)$ \\
3c & 2-OMe & $25(81)$ \\
3d & 2-Et & 24 \\
3e & 3-Me & 35 \\
3f & 4-F & 25 \\
4c & 2-OMe & 7 \\
4e & 3-Me & 8 \\
6c & 2-OMe & 71 \\
\hline
\end{tabular}


Application of weaker bases ( $N$-methylmorpholine, $\mathrm{Et}_{3} \mathrm{~N}$ in $\mathrm{EtOH}$ or $\left.\mathrm{DMF}\right)$ at room or elevated temperatures resulted in recovery of the starting materials. The use of DEEMM 2 taken in excess did not increase the yield of the minor products 4a-f, however, excess of sodium ethoxide allowed isolation of two representatives of the minor ester derivatives $\mathbf{4 c}, \mathbf{e}$ in small yields from the mother solutions (Table 1). To obtain the desired products $\mathbf{4 a , b}$ we also attempted to use dimethylformamide dimethylacetal (DMFDMA) as C-1-synthon in threecomponent or one-pot step-by-step reaction format (with initial interaction between diethyl malonate and DMFDMA). All these attempts resulted in the isolation of the known adducts $\mathbf{5 a}, \mathbf{b}^{13}$ which did not react with diethyl malonate.

The application of smaller amounts of sodium ethoxide ( 0.5 equiv) led to the isolation of open chain products 6 (Scheme 2) in the mixture with their isomers of type 3. One representative of such isomeric compounds bearing an ortho-methoxy group $\mathbf{6 c}$ was successfully isolated. This compound is stable enough in DMSO- $d_{6}$ during NMR measurements and could be purified by recrystallization. Heating of $\mathbf{6 c}$ in $\mathrm{EtOH}$ in the presence of sodium ethoxide resulted in the formation of 2-pyridone $3 \mathrm{c}$ in $80 \%$ yield.

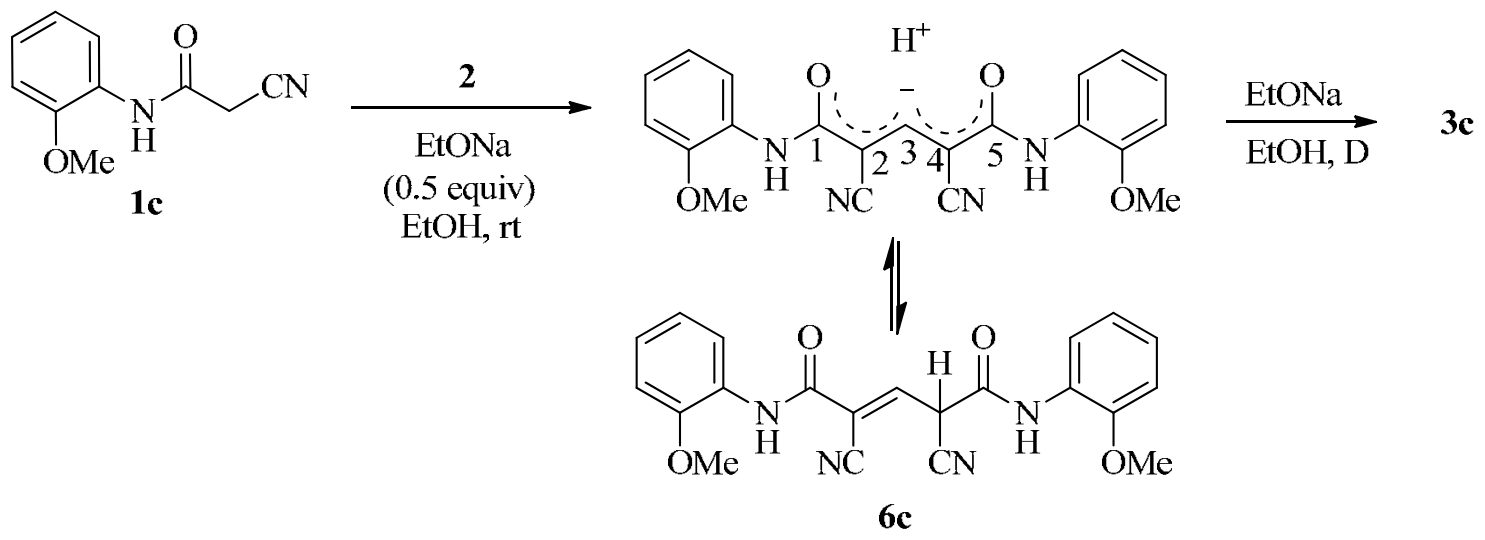

\section{Scheme 2}

We found in the literature only a single instance ${ }^{14}$ where a representative of the heterocyclic class 3 was obtained. Thus, to examine a possible alternative synthetic route to such molecules, and also to model one of the possible reaction stages of their formation from cyanoacetamides 1a-f and DEEMM 2 (Scheme 1) we utilized ethoxymethylene derivatives 7a-c (Scheme 3). Thus, their reaction with cyanoacetamides 1a-c under the same conditions resulted in formation of the desired derivatives 3a-c in very high yields (Table 1, Method B) without additional purification. 
<smiles>N#CCC(=O)Nc1cc#[R]cc1</smiles>

1a-c

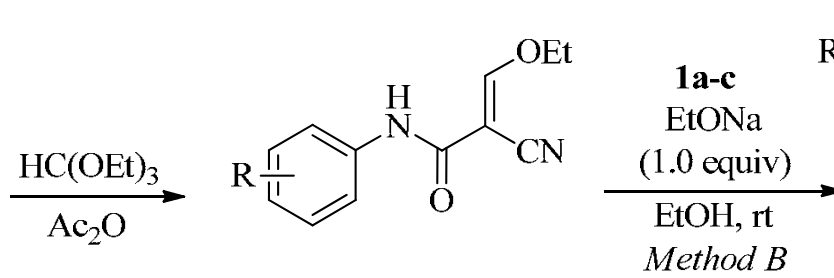

$7 \mathbf{a}-\mathbf{c}$<smiles>N#Cc1cc(C(=O)Nc2cc#[Y]cc2)c(N)n(C2#[Y]=CC=C2)c1=O</smiles>

\section{Scheme 3}

Comparing Methods A and B one should take into account that the Method B required the initial synthesis of ethoxymethylene compounds 7a-c which were obtained in $65-90 \%$ isolated yields (see Experimental Section for details).

\section{Structural elucidation}

The structure of the representative 3a (Schemes 1 and 3) is undoubtedly determined by single crystal X-ray analysis (Figure 1). Spectral data for 3a ( ${ }^{1} \mathrm{H}$ NMR, MS and IR spectra) are in accordance with this structure. It was interesting to compare the cyclic compound $\mathbf{3 c}$ with its open chain isomer $\mathbf{6 c}$ (Scheme 2). These compounds give the same mass of their molecular ions $\left(\mathrm{m} / \mathrm{z}=391,2[\mathrm{M}+1]^{+}\right)$, but differ in their IR characteristic bands, thus, a slightly split band of $\mathrm{CN}$-group in the acyclic compound $\mathbf{6 c}$ lies at $2195 \mathrm{~cm}^{-1}$, whereas the $\mathrm{CN}$-group of compound $\mathbf{3 c}$ appears at $2224 \mathrm{~cm}^{-1}$. The absorption of carbamide $\mathrm{C}=\mathrm{O}$ groups for compound $\mathbf{6 c}$ is found at $1626 \mathrm{~cm}^{-1}$, and at $1678 \mathrm{~cm}^{-1}$ for $3 \mathbf{c}$.

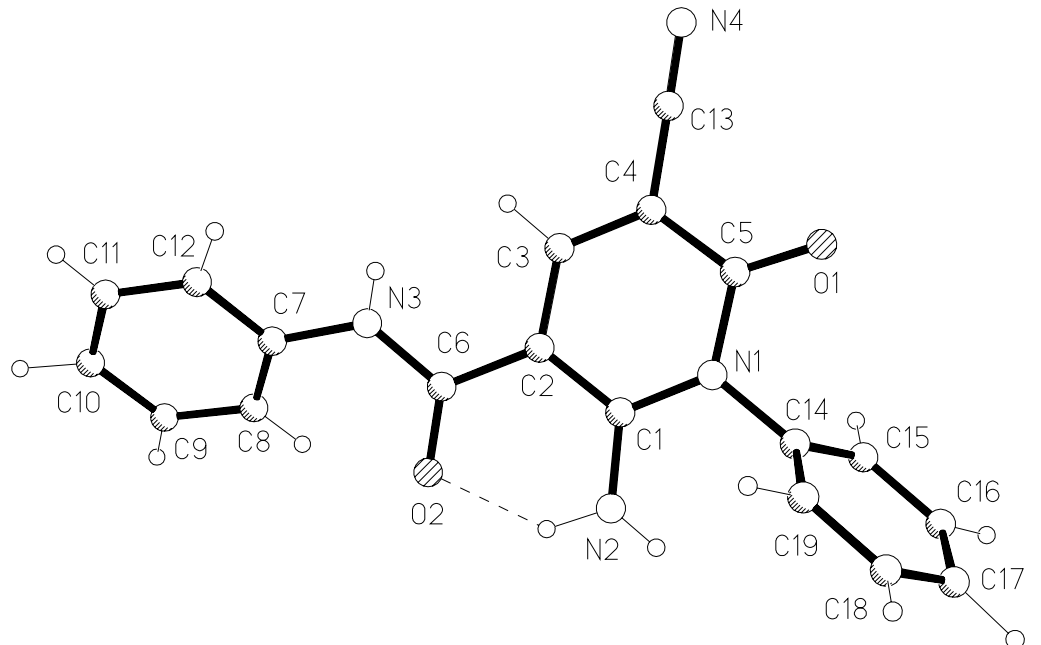

Figure 1. The molecular structure of compound 3a. Selected bond lengths $(\AA)$ and valence angles $\left({ }^{\circ}\right)$ in the molecule 3a: $\mathrm{C}^{1}-\mathrm{N}^{1} 1.370(2), \mathrm{C}^{5}-\mathrm{N}^{1} 1.416(2), \mathrm{C}^{1}-\mathrm{C}^{2} 1.419(2), \mathrm{C}^{2}-\mathrm{C}^{3} 1.392(2)$, $\mathrm{C}^{3}-\mathrm{C}^{4} 1.367(2), \mathrm{C}^{4}-\mathrm{C}^{5} 1.434(3), \mathrm{C}^{2}-\mathrm{C}^{6} 1.472(2), \mathrm{C}^{1}-\mathrm{N}^{2} 1.321(2), \mathrm{C}^{5}-\mathrm{O}^{1} 1.216(2), \mathrm{C}^{6}-\mathrm{N}^{3} 1.350(2)$; $\mathrm{N}^{1}-\mathrm{C}^{1}-\mathrm{C}^{2} 119.47(14), \mathrm{C}^{4}-\mathrm{C}^{3}-\mathrm{C}^{2} 122.95(16), \mathrm{C}^{3}-\mathrm{C}^{4}-\mathrm{C}^{5} 121.46(15), \mathrm{N}^{1}-\mathrm{C}^{5}-\mathrm{C}^{4} 114.17(15), \mathrm{C}^{1}-\mathrm{N}^{1}-$ $\mathrm{C}^{5} 124.48(14)$. 
The ${ }^{1} \mathrm{H}$ NMR spectrum of compound $\mathbf{6 c}$ shows $3-\mathrm{CH}$ proton signals at $8.28 \mathrm{ppm}$ (compared to $3 \mathbf{c}$, the corresponding singlet of $4-\mathrm{CH}$ proton is at $7.94 \mathrm{ppm}$ ) and it contains also one range of proton signals of two equivalent aromatic substituents with a double integral intensity, whereas two aromatic rings of $\mathbf{3 c}$ differ in their proton chemical shifts. The amide protons of this compound appear in the usual area for them $(8.66,9.45 \mathrm{ppm})$, for the open chain isomer $\mathbf{6 c}$ one broad signal of its amide groups is located at $8.20 \mathrm{ppm}$ probably due to the efficient conjugation and distribution of the charge in the anion form. The signal of 2-/4-CH proton is absent in the ${ }^{1} \mathrm{H}$ NMR spectrum of $\mathbf{6 c}$ in DMSO- $d_{6}$ probably due to fast deuterium exchange. However in the ${ }^{13} \mathrm{C}$ NMR spectrum, a signal at $75.13 \mathrm{ppm}$ can be obviously assigned to the 2-/4-CH carbons. This signal does not appear in the DEPT also demonstrating the mobility of this $\mathrm{CH}$ proton.

\section{Possible reaction mechanisms}

In view of the chemical behavior of DEEMM in the reactions with 2-cyanoacetanilides and the determined structures of the products $3, \mathbf{4}$ and $\mathbf{6}$ one can consider two possible reaction pathways to the diaryl derivatives 3 (Scheme 4). The first suggests initial transfer of the ethoxymethylene moiety from DEEMM onto the active cyanomethylene compound $\mathbf{1}$ giving ethoxymethylene derivative 7 (analogous behavior was previously observed for DMFDMA adducts, ${ }^{10}$ see also Schemes 1 and 3), which then reacts with another molecule 1 giving an open chain kinetic product $\mathbf{6}$ which after base catalyzed cyclization gives pyridone 3 (Route A).

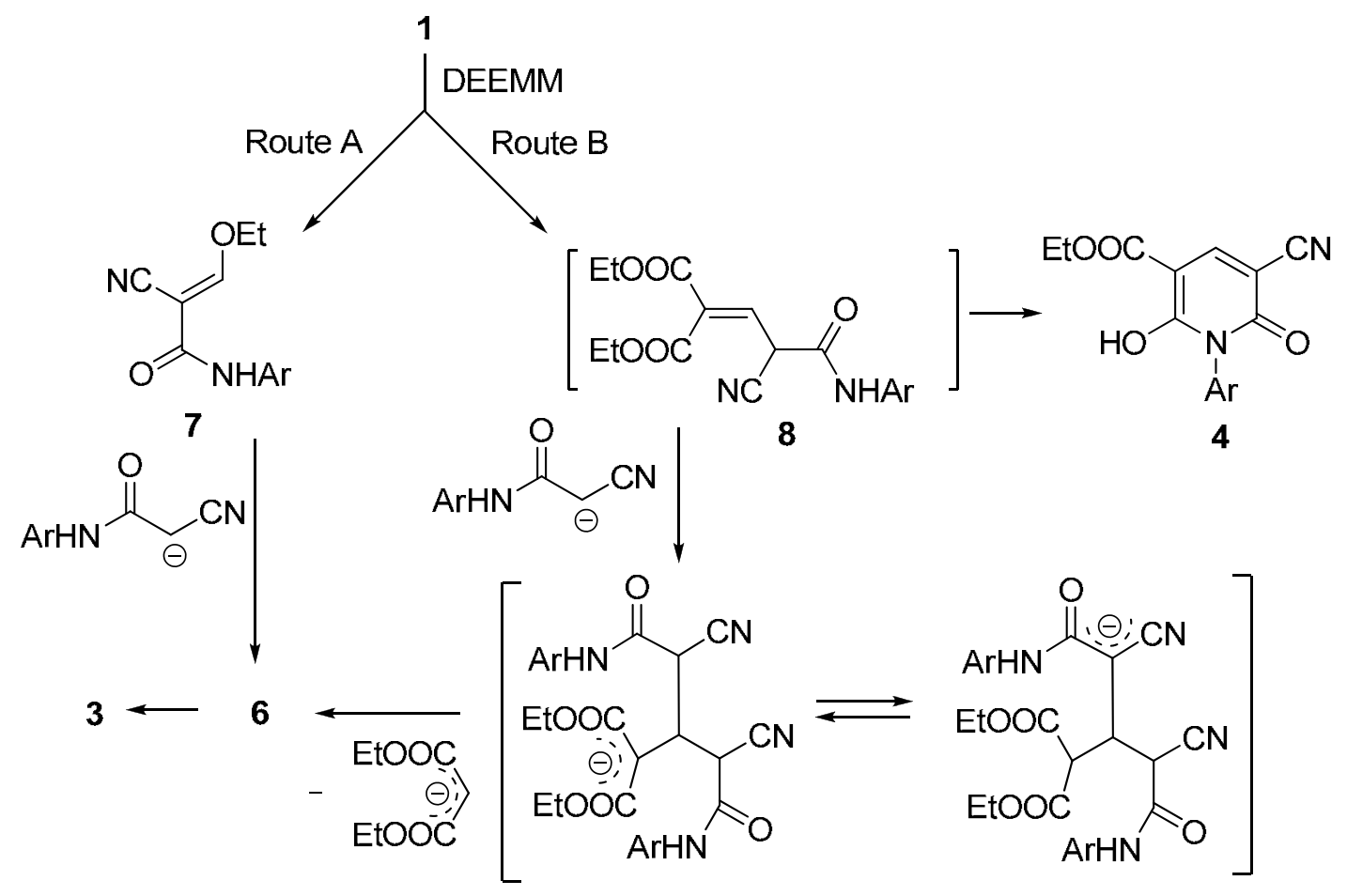

\section{Scheme 4}


On the other hand, the formation of the minor product 4 proceeds via conjugate addition of the methylene active nitrile $\mathbf{1}$ to DEEMM. Intermediate $\mathbf{8}$ that meanwhile may undergo a Michael addition of the second molecule of $\mathbf{1}$, as showed on the Scheme 4, and after elimination of diethylmalonate finally results in formation of pyridone 3 (Route B).

\section{Conclusions}

Interaction of $N$-substituted cyanoacetamides 1a-f with DEEMM 2 in the presence of sodium ethoxide (1.0 equiv) at room temperature proceeds via two competing reaction pathways resulting in formation of diaryl derivatives 3a-f and admixtures of ethyl carboxylates 4a-f. Application of lower amounts of sodium ethanolate was favorable for isolation of acyclic intermediate $\mathbf{6 c}$ which was transformed into the corresponding pyridone $\mathbf{3 c}$.

\section{Experimental Section}

General. The IR spectra were recorded on a FIR «Spectrum One» (PerkinElmer) in $\mathrm{KBr}$. Melting points were determined on a Koeffler apparatus. ${ }^{1} \mathrm{H}$ and ${ }^{13} \mathrm{C}$ NMR spectra were recorded on Varian Mercury VX-200 and Bruker Avance DRX 500 spectrometers in DMSO- $d_{6}$ with TMS as an external standard. LC/MS data were recorded using chromatography/mass spectrometric system "Agilent 1100 Series" equipped with a diode-matrix and massselective detector "Agilent LC/MSD SL" with Zorbax SB-C18, $1.8 \mu \mathrm{m}, 4.6 \mathrm{~mm} \times 15 \mathrm{~mm}$ column using eluents: A, acetonitrile/water (95:5), 0.1\% TFA; B, water (0.1\% of TFA) and eluent flow: $3 \mathrm{~mL} / \mathrm{sec}$. Volume of the injected sample was $1 \mu \mathrm{L}$. UV detectors were operated at 215, 254, and $265 \mathrm{~nm}$. Chemical ionization under atmospheric pressure was used in MS detector. Ionization mode: simultaneous scanning of positive and negative ions in the mass range of 80-1000 m/z. Elemental analysis was carried out on an EuroVector EA-3000 instrument. TLC was performed on Silufol UV-254 plates with eluent system: acetone-hexane (3:5), visualization: UV light, iodine vapors.

\section{X-Ray structure determination for (3a)}

Crystal data: $\mathrm{C}_{19} \mathrm{H}_{14} \mathrm{~N}_{4} \mathrm{O}_{2}, \mathrm{M} 330.34$, monoclinic, space group $\mathrm{P} 2{ }_{1}, a=9.2159(14), b=$ 8.2387(12), $c=10.8726(17) \AA, \beta=93.054(5)^{\circ}, \mathrm{V}=824.4(2) \AA^{3}, \mathrm{Z}=2, \mathrm{~d}_{\mathrm{c}}=1.331 \mathrm{~g} \cdot \mathrm{cm}^{-3}, \mu$ $0.090 \mathrm{~mm}^{-1}, \mathrm{~F}(000) 344$ crystal size ca. $0.40 \times 0.28 \times 0.13 \mathrm{~mm}$. All crystallographic measurements were performed at room temperature on a Bruker Smart Apex II diffractometer operating in the $\omega$ and $\varphi$ scans mode. The cell parameters were obtained from the least-squares treatment of 1918 reflections in the $\theta$. range of $2.82-26.55^{\circ}$. The intensity data were collected within the range of $2.82 \leq \theta \leq 29.49^{\circ}$ using Mo- $K_{\alpha}$ radiation $(\lambda=0.71078 \AA)$. The intensities of 5873 reflections were collected (3856 unique reflections, $\mathrm{R}_{\text {merg }}=0.0217$ ). Data were corrected for Lorentz and polarization effects. The SADABS absorption correction (the ratio of minimum 
to maximum apparent transmission is 0.653252 ) was applied. The structure was solved by direct methods and refined by the full-matrix least-squares technique in the anisotropic approximation for non-hydrogen atoms using the SHELXS97 and SHELXL97 programs. ${ }^{16,17}$ All hydrogen atoms were refined isotropically. In the refinement 3856 independent reflections (3026 reflections with $\mathrm{I} \geq 2 \sigma(\mathrm{I})$ ) were used. Convergence was obtained at $\mathrm{R} 1=0.0597$ and $\mathrm{wR} 2=$ $0.0962, \mathrm{GOF}=1.003$ for all reflection and $\mathrm{R} 1=0.0420$ and $\mathrm{wR} 2=0.0867$, GOF $=1.003$ for observed (282 parameters; observed/variable ratio 10.7; the largest and minimal peaks in the final difference map 0.13 and $-0.31 \mathrm{e} / \AA^{3}$, weighting scheme is as follows: $\omega=1 /\left[\sigma^{2}\left(\mathrm{Fo}^{2}\right)+\right.$ $\left.(0.0442 \mathrm{P})^{2}+0.0316 \mathrm{P}\right]$, where $\left.\mathrm{P}=\left(\mathrm{Fo}^{2}+2 \mathrm{Fc}^{2}\right) / 3\right)$, Flack parameter $0.0(12)$, thus absolute configuration was not determined because of absence of heavy atoms. Full crystallographic details have been deposited at Cambridge Crystallographic Data Centre (CCDC). Any request to the CCDC for these materials should quote the full literature citation and reference number CCDC 784198.

\section{Preparation of compounds (3a-f, 4c,e) and (6c). Method A}

Sodium $(0.005 \mathrm{~mol})$ was dissolved in $2 \mathrm{~mL}$ of abs. EtOH. To this solution the appropriate $\mathrm{CH}-$ acid 1a-f $(0.005 \mathrm{~mol})$ was added and stirred for $5 \mathrm{~min}$ at $\mathrm{rt}$. DEEMM $2(0.005 \mathrm{~mol})$ was added to the mixture and stirred for $1 \mathrm{~h}$ at $\mathrm{rt}$. The precipitate 3 was filtered off and washed with ethanol and hexane, crystallized from DMF (for 3a-c,f) or butanol-1 (for 3d,e).

Compounds $4 \mathbf{c}$,e were isolated following this procedure with a use of $0.01 \mathrm{~mol}$ of EtONa. To the filtrate from precipitation of $31 \mathrm{~mL}$ of $10 \% \mathrm{KOH}$ aqueous solution was added and the precipitates 4c,e was left overnight was filtered off and washed with ethanol and hexane. Recrystallisation was performed from butanol-1 $\mathbf{4 c}$ or DMF $4 \mathbf{e}$.

Compound 6c was obtained in $71 \%$ yield following method A using 2.5 mmol sodium ethanolate. The product was recrystallized from acetone.

\section{Preparation of compounds (3a-f). Method B}

Initial compounds $7 \mathbf{a}-\mathbf{c}$ were obtained by slightly modified procedure described previously. ${ }^{15} \mathrm{~A}$ mixture of $0.02 \mathrm{~mol}$ of the appropriate $\mathrm{CH}$-acid 1a-c and triethylorthoformiate $(0.04 \mathrm{~mol})$ was refluxed in $0.06 \mathrm{~mL}$ of acetic anhydride. Then volatile waste-products were slowly distilled off at atmosphere pressure until temperature reached $82{ }^{\circ} \mathrm{C}$. The precipitate of $7 \mathbf{a}-\mathbf{c}$ formed on cooling was filtered off, washed with dry cold methanol and after drying was used for the next step without additional purification. Yields: $81 \% \mathbf{7 a}, 78 \% \mathbf{7 b}, 60 \% \mathbf{7 c}$.

Sodium $(0.005 \mathrm{~mol})$ was dissolved in $2 \mathrm{~mL}$ of abs. EtOH. To this solution the appropriate $\mathrm{CH}-$ acid 1a-c $(0.005 \mathrm{~mol})$ was added and stirred for $5 \mathrm{~min}$ at $\mathrm{rt}$. The appropriate ethoxymethylene derivative $7 \mathbf{a}-\mathbf{c}(0.005 \mathrm{~mol})$ was added to the mixture and stirred for $1 \mathrm{~h}$ at $\mathrm{rt}$. The precipitate 3ac was filtered off and washed with ethanol and hexane.

2-Amino-5-cyano-6-oxo- $N$,1-diphenyl-1,6-dihydropyridine-3-carboxamide (3a). Yellow crystals (from DMF); mp 295-296 ${ }^{\circ} \mathrm{C}$. IR (KBr) cm ${ }^{-1}: 3320\left(\mathrm{NH}_{2}, \mathrm{NH}\right), 2218(\mathrm{C} \equiv \mathrm{N}), 1682$ $(\mathrm{C}=\mathrm{O}), 1538,1588\left(\delta \mathrm{NH}_{2}, \mathrm{NH}\right) .{ }^{1} \mathrm{H} \mathrm{NMR}\left(500 \mathrm{MHz}, \mathrm{DMSO}-d_{6}\right) \delta 7.09\left(\mathrm{t}, J=6.7 \mathrm{~Hz}, 1 \mathrm{H}, \mathrm{H}_{\mathrm{Ar}}\right)$, 
$7.33\left(\mathrm{~m}, 4 \mathrm{H}, \mathrm{H}_{\mathrm{Ar}}\right), 7.57\left(\mathrm{~m}, 5 \mathrm{H}, \mathrm{H}_{\mathrm{Ar}}\right), 8.69\left(\mathrm{~s}, 1 \mathrm{H}, \mathrm{C}^{4} \mathrm{H}\right), 9.91(\mathrm{~s}, 1 \mathrm{H}, \mathrm{NHAr})$, no $\mathrm{NH}_{2}$ signals was observed, presumably due to fast deutroexchange. LC/MS, $m / z$ (\%): 331.2 (100) [M+1] $]^{+}$. ${ }^{13} \mathrm{C}$ NMR $\left(50 \mathrm{MHz}, \mathrm{DMSO}-d_{6}\right) \delta 85.54,93.74,118.27,121.44,124.16,129.15,130.22,130.73$, 134.32, 139.05, 145.64, 157.56, 160.11, 165.24. Anal. Calcd for $\mathrm{C}_{19} \mathrm{H}_{14} \mathrm{~N}_{4} \mathrm{O}_{2}: \mathrm{C}, 69.1 ; \mathrm{H}, 4.3 ; \mathrm{N}$, 16.9. Found: C, $69.3 ; \mathrm{H}, 4.1 ; \mathrm{N}, 16.8$.

2-Amino-5-cyano-6-oxo- $N$,1-di-(p-tolyl)-1,6-dihydropyridine-3-carboxamide (3b). Pale yellow powder (from DMF); mp 287-288 ${ }^{\circ} \mathrm{C}$. IR $(\mathrm{KBr}) \mathrm{cm}^{-1}: 3397\left(\mathrm{NH}_{2}, \mathrm{NH}\right), 2224(\mathrm{C} \equiv \mathrm{N})$, $1678(\mathrm{C}=\mathrm{O}), 1581,1539\left(\delta \mathrm{NH}_{2}, \mathrm{NH}\right) .{ }^{1} \mathrm{H}$ NMR $\left(500 \mathrm{MHz}, \mathrm{DMSO}-d_{6}\right) \delta 2.29\left(\mathrm{~s}, 3 \mathrm{H}, \mathrm{CH}_{3}\right), 2.43$ $\left(\mathrm{s}, 3 \mathrm{H}, \mathrm{CH}_{3}\right), 7.16\left(\mathrm{~d}, J=8.15 \mathrm{~Hz}, 2 \mathrm{H}, \mathrm{H}_{\mathrm{Ar}}\right), 7.25\left(\mathrm{~d}, J=7.89 \mathrm{~Hz}, 2 \mathrm{H}, \mathrm{H}_{\mathrm{Ar}}\right), 7.43(\mathrm{~d}, J=7.84 \mathrm{~Hz}$, $\left.2 \mathrm{H}, \mathrm{H}_{\mathrm{Ar}}\right), 7.51\left(\mathrm{~d}, J=8.24 \mathrm{~Hz}, 2 \mathrm{H}, \mathrm{H}_{\mathrm{Ar}}\right), 8.69$ (s, 1H, $\left.C^{4} \mathrm{H}\right), 9.87$ (s, 1H, NHAr), no $\mathrm{NH}_{2}$ signal was observed, presumably due to fast deutroexchange. LC/MS, $m / z(\%): 359.0(100)[\mathrm{M}+1]^{+}$. ${ }^{13} \mathrm{C}$ NMR $\left(50 \mathrm{MHz}, \mathrm{DMSO}-d_{6}\right) \delta 20.39,20.89,74.43,119.68,120.99,128.26,128.79,128.92$, $131.10,132.64,136.17,137.39,139.08,145.82,147.56,157.20,164.54$. Anal. Calcd for $\mathrm{C}_{21} \mathrm{H}_{18} \mathrm{~N}_{4} \mathrm{O}_{2}$ : C, 70.4; H, 5.1; N, 15.6. Found: C, 70.1; H, 4.9; N, 15.3.

2-Amino-5-cyano- $N$,1-di-(2-methoxyphenyl)-6-oxo-1,6-dihydropyridine-3-carboxamide

(3c). Red crystals (from DMF); mp 260-261 ${ }^{\circ} \mathrm{C}$. IR (KBr) cm ${ }^{-1}: 3397\left(\mathrm{NH}_{2}, \mathrm{NH}\right), 2224(\mathrm{C} \equiv \mathrm{N})$, $1678(\mathrm{C}=\mathrm{O}), 1581\left(\delta \mathrm{NH}_{2}, \mathrm{NH}\right) .{ }^{1} \mathrm{H} \mathrm{NMR}\left(500 \mathrm{MHz}, \mathrm{DMSO}-d_{6}\right) \delta 3.76\left(\mathrm{~s}, 3 \mathrm{H}, \mathrm{OCH}_{3}\right), 3.81(\mathrm{~s}$, $\left.3 \mathrm{H}, \mathrm{OCH}_{3}\right), 6.93$ (t, $\left.J=7.52 \mathrm{~Hz}, 1 \mathrm{H}, \mathrm{H}_{\mathrm{Ar}}\right), 7.07$ (d, $\left.J=8.17 \mathrm{~Hz}, 1 \mathrm{H}, \mathrm{H}_{\mathrm{Ar}}\right), 7.13(\mathrm{t}, J=7.54 \mathrm{~Hz}$, $\left.1 \mathrm{H}, \mathrm{H}_{\mathrm{Ar}}\right), 7.19\left(\mathrm{t}, J=7.82 \mathrm{~Hz}, 1 \mathrm{H}, \mathrm{H}_{\mathrm{Ar}}\right), 7.28\left(\mathrm{t}, J=9.11 \mathrm{~Hz}, 2 \mathrm{H}, \mathrm{H}_{\mathrm{Ar}}\right), 7.40(\mathrm{~d}, J=7.66 \mathrm{~Hz}, 1 \mathrm{H}$, $\left.\mathrm{H}_{\mathrm{Ar}}\right), 7.54\left(\mathrm{t}, J=7.48 \mathrm{~Hz}, 1 \mathrm{H}, \mathrm{H}_{\mathrm{Ar}}\right), 7.94(\mathrm{~s}, 1 \mathrm{H}, \mathrm{NH}), 8.66\left(\mathrm{~s}, 1 \mathrm{H}, \mathrm{C}^{4} \mathrm{H}\right), 9.45\left(\mathrm{~s}, \mathrm{NH}_{2}\right)$, signal of $\mathrm{NH}_{2}$ group has decreased intensity. ${ }^{13} \mathrm{C}$ NMR $\left(50 \mathrm{MHz}, \mathrm{DMSO}-d_{6}\right) \delta 56.47,56.56,77.77$, $101.84,111.87,113.83,120.64,121.08,121.94,122.12,122.42,130.48,130.99,132.04,145.34$, 149.58, 156.76, 158.26, 164.18. LC/MS, $m / z(\%): 388.8[M-1]^{+}$(100). Anal. Calcd for $\mathrm{C}_{21} \mathrm{H}_{17} \mathrm{~N}_{4} \mathrm{O}_{4}$ : C, 64.6; H, 4.7; N, 14.4. Found: C, 56.4; H, 5.1; N, 12.5.

2-Amino-5-cyano- $N$,1-di-(2-ethylphenyl)-6-oxo-1,6-dihydropyridine-3-carboxamide (3d). Pale yellow powder (from $\mathrm{BuOH}$ ); mp 238-239 ${ }^{\circ} \mathrm{C}$. IR $(\mathrm{KBr}) \mathrm{cm}^{-1}: 3454,3327\left(\mathrm{NH}_{2}, \mathrm{NH}\right), 2213$ $(\mathrm{C} \equiv \mathrm{N}), 1666(\mathrm{C}=\mathrm{O}), 1516\left(\delta \mathrm{NH}_{2}, \mathrm{NH}\right) .{ }^{1} \mathrm{H}$ NMR $\left(500 \mathrm{MHz}, \mathrm{DMSO}-d_{6}\right) \delta 1.10(\mathrm{t}, J=7.63 \mathrm{~Hz}$, $\left.3 \mathrm{H}, \mathrm{CH}_{3}\right), 1.13\left(\mathrm{t}, J=7.58 \mathrm{~Hz}, 3 \mathrm{H}, \mathrm{CH}_{3}\right), 2.32\left(\mathrm{dd}, J=7.43,4.2 \mathrm{~Hz}, 2 \mathrm{H}, \mathrm{CH}_{2}\right), 2.59(\mathrm{q}, J=$ 7.41, 4.2 Hz, 2H, $\left.\mathrm{CH}_{2}\right), 7.20\left(\mathrm{~d}, J=7.18 \mathrm{~Hz}, 2 \mathrm{H}, \mathrm{H}_{\mathrm{Ar}}\right), 7.22\left(\mathrm{~d}, J=7.16 \mathrm{~Hz}, 1 \mathrm{H}, \mathrm{H}_{\mathrm{Ar}}\right), 7.27(\mathrm{~m}$, $\left.2 \mathrm{H}, \mathrm{H}_{\mathrm{Ar}}\right), 7.42\left(\mathrm{~m}, 1 \mathrm{H}, \mathrm{H}_{\mathrm{Ar}}\right), 7.52$ (d, $\left.J=4.18 \mathrm{~Hz}, 2 \mathrm{H}, \mathrm{H}_{\mathrm{Ar}}\right), 8.72\left(\mathrm{~s}, 1 \mathrm{H}, \mathrm{C}^{4} \mathrm{H}\right), 9.69$ (s, 1H, $\mathrm{NHAr}$, no $\mathrm{NH}_{2}$ signal was observed, presumably due to fast deuteron-exchange. ${ }^{13} \mathrm{C} \mathrm{NMR}$, DEPT $\left(50 \mathrm{MHz}\right.$, DMSO-d $\left.d_{6}\right) \delta 19.1\left(\mathrm{CH}_{3}\right), 19.6\left(\mathrm{CH}_{3}\right), 28.5\left(\mathrm{CH}_{2}\right), 29.3\left(\mathrm{CH}_{2}\right), 131.4(\mathrm{CH})$, 132.1(CH), 133.2(CH), 133,4(CH), 133.8(CH), 134.2(CH), 135.3(CH), 135.7(CH), 151.8(CH). LC/MS, $m / z(\%): 387.2(100)[\mathrm{M}+1]^{+}, 99.2$ (5). Anal. Calcd for $\mathrm{C}_{23} \mathrm{H}_{22} \mathrm{~N}_{4} \mathrm{O}_{2}$ : C, 71.5; H, 5.7; N, 14.5. Found: C, 71.4; H, 6.0; N, 14.4.

2-Amino-5-cyano-6-oxo- $N$,1-di-(m-tolyl)-1,6-dihydropyridine-3-carboxamide (3e). Yellow powder (from $\mathrm{BuOH})$; mp 330-331 ${ }^{\circ} \mathrm{C}$. IR (KBr) cm $\mathrm{cm}^{-1}: 3409,3294\left(\mathrm{NH}_{2}, \mathrm{NH}\right), 2212(\mathrm{C} \equiv \mathrm{N})$, $1662(\mathrm{C}=\mathrm{O}), 1557\left(\delta \mathrm{NH}_{2}, \mathrm{NH}\right) .{ }^{1} \mathrm{H} \mathrm{NMR}\left(500 \mathrm{MHz}, \mathrm{DMSO}-d_{6}\right) \delta 2.29\left(\mathrm{~s}, 3 \mathrm{H}, \mathrm{CH}_{3}\right), 2.37(\mathrm{~s}$, $\left.3 \mathrm{H}, \mathrm{CH}_{3}\right), 6.91\left(\mathrm{~s}, 1 \mathrm{H}, \mathrm{H}_{\mathrm{Ar}}\right), 7.18\left(\mathrm{~m}, 3 \mathrm{H}, \mathrm{H}_{\mathrm{Ar}}\right), 7.41\left(\mathrm{~m}, 2 \mathrm{H}, \mathrm{H}_{\mathrm{Ar}}\right), 7.46\left(\mathrm{~m}, 2 \mathrm{H}, \mathrm{H}_{\mathrm{Ar}}\right), 8.67(\mathrm{~s}, 1 \mathrm{H}$, $\left.\mathrm{C}^{4} \mathrm{H}\right), 9.84$ (s, 1H, NHAr), no $\mathrm{NH}_{2}$ signal was observed, presumably due to fast deuteron- 
exchange. LC/MS, $m / z(\%): 359.0(100)[\mathrm{M}+1]^{+} .{ }^{13} \mathrm{C}$ NMR $\left(50 \mathrm{MHz}, \mathrm{DMSO}-d_{6}\right) \delta 21.35,21.66$, $118.38,118.44,118.50,121.90,124.87,126.04,128.88,129.45,130.64,130.95,134.36,138.21$, 139.07, 140.47, 146.61, 157.67, 160.14, 165.24. Anal. Calcd for $\mathrm{C}_{21} \mathrm{H}_{18} \mathrm{~N}_{4} \mathrm{O}_{2}$ : C, 70.4; $\mathrm{H}, 5.1 ; \mathrm{N}$, 15.6. Found: C, 70.0; H, 4.9; N, 15.0.

2-Amino-5-cyano- $N$,1-di-(4-fluorophenyl)-6-oxo-1,6-dihydropyridine-3-carboxamide (3f). Yellow powder (from DMF); mp 322-324 ${ }^{\circ} \mathrm{C}$. IR (KBr) cm ${ }^{-1}: 3439\left(\mathrm{NH}_{2}, \mathrm{NH}\right), 2224(\mathrm{C} \equiv \mathrm{N})$, $1668(\mathrm{C}=\mathrm{O}), 1596,1537\left(\delta \mathrm{NH}_{2}, \mathrm{NH}\right) .{ }^{1} \mathrm{H}$ NMR $\left(500 \mathrm{MHz}, \mathrm{DMSO}-d_{6}\right) \delta 7.17(\mathrm{t}, J=8.61 \mathrm{~Hz}$, $\left.2 \mathrm{H}, \mathrm{H}_{\mathrm{Ar}}\right), 7.44\left(\mathrm{~d}, J=6.48 \mathrm{~Hz}, 4 \mathrm{H}, \mathrm{H}_{\mathrm{Ar}}\right), 7.61\left(\mathrm{~m}, 2 \mathrm{H}, \mathrm{H}_{\mathrm{Ar}}\right), 8.65\left(\mathrm{~s}, 1 \mathrm{H}, \mathrm{C}^{4} \mathrm{H}\right), 9.96($ br s, $1 \mathrm{H}$, $\mathrm{NH}$ ), no $\mathrm{NH}_{2}$ signal was observed, presumably due to fast deuteron-exchange with water present in the solvent. ${ }^{13} \mathrm{C}$ NMR $\left(50 \mathrm{MHz}, \mathrm{DMSO}-d_{6}\right) \delta 85.99,93.99,115.52,115.96,117.72,118.18$, $123.69,123.84,130.81,131.88,135.55,146.86,156.87,158.15,160.24,161.65,165.56,165.80$. LC/MS, $m / z(\%): 367.0[M+1]^{+}(100), 124.2$ (10). Anal. Calcd for $\mathrm{C}_{19} \mathrm{H}_{12} \mathrm{~F}_{2} \mathrm{~N}_{4} \mathrm{O}_{2}$ : C, 62.3; H, 3.3; N, 15.3. Found: C, 62.0; H, 2.9; N, 14.9. $M=366.32$.

Ethyl 5-cyano-2-hydroxy-1-(2-methoxyphenyl)-6-oxo-1,6-dihydropyridine-3-carboxylate (4c). Yellow powder (from $\mathrm{BuOH}$ ); mp 180-183 ${ }^{\circ} \mathrm{C}$. IR $(\mathrm{KBr}) \mathrm{cm}^{-1}: 3400\left(\mathrm{NH}_{2}, \mathrm{NH}\right), 2216$ $(\mathrm{C} \equiv \mathrm{N}), 1672(\mathrm{C}=\mathrm{O}) .{ }^{1} \mathrm{H}$ NMR $\left(200 \mathrm{MHz}, \mathrm{DMSO}-d_{6}\right) \delta 1.18\left(\mathrm{t}, J=6.90 \mathrm{~Hz}, 3 \mathrm{H}, \mathrm{CH}_{2} \underline{\mathrm{CH}}_{3}\right), 3.85$ $\left(\mathrm{s}, 3 \mathrm{H}, \mathrm{OCH}_{3}\right), 4.06\left(\mathrm{q}, J=6.90 \mathrm{~Hz}, 2 \mathrm{H}, \underline{\mathrm{CH}}_{2} \mathrm{CH}_{3}\right), 6.88\left(\mathrm{t}, J=7.38 \mathrm{~Hz}, 1 \mathrm{H}, \mathrm{H}_{\mathrm{Ar}}\right), 6.96(\mathrm{t}, J=$ $\left.7.72 \mathrm{~Hz}, 1 \mathrm{H}, \mathrm{H}_{\mathrm{Ar}}\right), 7.02$ (d, $\left.J=7.85 \mathrm{~Hz}, 1 \mathrm{H}, \mathrm{H}_{\mathrm{Ar}}\right), 8.13\left(\mathrm{~s}, 1 \mathrm{H}, \mathrm{C}^{4} \mathrm{H}\right), 8.21$ (br s, $\left.1 \mathrm{H}, \mathrm{OH}\right), 8.25$ $\left(\mathrm{d}, J=7.77 \mathrm{~Hz}, 1 \mathrm{H}, \mathrm{H}_{\mathrm{Ar}}\right) .{ }^{13} \mathrm{C} \mathrm{NMR}\left(50 \mathrm{MHz}, \mathrm{DMSO}-d_{6}\right) \delta 15.10,56.53,59.58,72.78,75.14$, 111.12 , 118.89, 118.99, 120.16, 121.07, 123.05, 128.82, 148.09, 149.22, 163.65, 167.22. LC/MS, $m / z(\%): 315.0$ (100) $[\mathrm{M}+1]^{+}, 287.0$ (10). Anal. Calcd for $\mathrm{C}_{16} \mathrm{H}_{14} \mathrm{~N}_{2} \mathrm{O}_{5}$ : C, 61.1; H, 4.5; N, 8.9. Found: C, 61.4; H, 4.3; N, 8.5. $M=314.29$.

Ethyl 5-cyano-2-hydroxy-6-oxo-1-m-tolyl-1,6-dihydropyridine-3-carboxylate (4e). Yellow powder (from DMF); mp $184{ }^{\circ} \mathrm{C}$. IR (KBr) cm ${ }^{-1}: 2213(\mathrm{C} \equiv \mathrm{N}), 1722,1693(\mathrm{C}=\mathrm{O}) .{ }^{1} \mathrm{H}$ NMR $(500$ $\left.\mathrm{MHz}, \mathrm{DMSO}-d_{6}\right) \delta 1.28\left(\mathrm{t}, J=7.1 \mathrm{~Hz}, 3 \mathrm{H}, \mathrm{CH}_{2} \underline{\mathrm{CH}}_{3}\right), 2.35\left(\mathrm{~s}, 3 \mathrm{H}, \mathrm{ArCH}_{3}\right), 4.21(\mathrm{q}, 2 \mathrm{H}$, $\left.\underline{\mathrm{CH}_{2}} \mathrm{CH}_{3}\right), 6.82\left(\mathrm{~d}, J=7.7 \mathrm{~Hz}, 1 \mathrm{H}, \mathrm{H}_{\mathrm{Ar}}\right), 6.89\left(\mathrm{~s}, 1 \mathrm{H}, \mathrm{H} \mathrm{H}_{\mathrm{Ar}}\right), 7.12\left(\mathrm{~d}, J=7.7 \mathrm{~Hz}, 1 \mathrm{H}, \mathrm{H}_{\mathrm{Ar}}\right), 7.26$ $\left(\mathrm{t}, J=7.7 \mathrm{~Hz}, 1 \mathrm{H}, \mathrm{H}_{\mathrm{Ar}}\right), 8.12\left(\mathrm{~s}, 1 \mathrm{H}, \mathrm{C}^{4} \mathrm{H}\right)$, no $\mathrm{OH}$ signal was observed, presumably due to fast deuteron-exchange. ${ }^{13} \mathrm{C}$ NMR $\left(50 \mathrm{MHz}, \mathrm{DMSO}-d_{6}\right) \delta 10.91,14.94,26.12,59.00,62.97,79.87$, 98.66, 120.47, 126.78, 128.00, 128.69, 130.28, 138.11, 148.40, 162.41, 164.97. LC/MS, $m / z(\%)$ : 298.8 (100) $[\mathrm{M}+1]^{+}, 252.8$ (25). Anal. Calcd for $\mathrm{C}_{16} \mathrm{H}_{14} \mathrm{~N}_{2} \mathrm{O}_{4}: \mathrm{C}, 64.4 ; \mathrm{H}, 4.7 ; \mathrm{N}, 9.4$. Found: C, 64.0; H, 4.9; N, 9.7.

2,4-Dicyano-N1,N5-di-(2-methoxyphenyl)pent-2-enediamide (6c). Yellow needles (from acetone); mp 255-256 ${ }^{\circ} \mathrm{C}$. IR $(\mathrm{KBr}) \mathrm{cm}^{-1}: 3379(\mathrm{NH}), 2195(\mathrm{C} \equiv \mathrm{N}), 1626(\mathrm{C}=\mathrm{O}), 1595,1531(\delta$ $\mathrm{NH}) .{ }^{1} \mathrm{H}$ NMR $\left(200 \mathrm{MHz}, \mathrm{DMSO}-d_{6}\right) \delta 3.85\left(\mathrm{~s}, 6 \mathrm{H}, 2 \mathrm{OCH}_{3}\right), 6.88\left(\mathrm{t}, J=6.96 \mathrm{~Hz}, 2 \mathrm{H}, \mathrm{H}_{\mathrm{Ar}}\right), 6.96$ $\left(\mathrm{t}, J=6.96 \mathrm{~Hz}, 2 \mathrm{H}, \mathrm{H}_{\mathrm{Ar}}\right), 7.01(\mathrm{~d}, J=7.32 \mathrm{~Hz}, 2 \mathrm{H}), 8.19\left(\mathrm{~d}, 2 \mathrm{H}, \mathrm{C}^{3-4}\right), 8.22(\mathrm{~s}, 1 \mathrm{H}, \mathrm{NH}), 8.25(\mathrm{~d}$, $J=6.75 \mathrm{~Hz}, 2 \mathrm{H}, \mathrm{H}_{\mathrm{Ar}}$ ), no $\mathrm{NH}$ signal was observed, presumably due to fast deuteron-exchange.

${ }^{13} \mathrm{C}$ NMR, DEPT (50 MHz, DMSO- $\left.d_{6}\right) \delta 152.9(\mathrm{CH}), 127.8(\mathrm{CH}), 126.05(\mathrm{CH}), 124.1(\mathrm{CH})$, $116.2(\mathrm{CH}), 61.55\left(\mathrm{CH}_{3}\right)$. LC/MS, $m / z(\%): 391.2[M+1]^{+}(100), 124.2$ (25). Anal. Calcd for $\mathrm{C}_{21} \mathrm{H}_{18} \mathrm{~N}_{4} \mathrm{O}_{4}$ : C, 64.6; H, 4.7; N, 14.4. Found: C, 64.4; H, 4.5; N, 14.5. 


\section{Acknowledgements}

Valeriya P. Tkachova partially performed this work in SSI "Institute for Single Crystals", we kindly thank Prof. Dr. Sergey M. Desenko for this opportunity. We also grateful to Enamine Ltd (Kiev, Ukraine) for their gratuitous LC/MS services.

\section{References and Notes}

1. Henry, G. H. Tetrahedron 2004, 60, 6043. (b) Torres, M; Gil, S; Parra, M. Curr. Org. Chem. 2005, 9, 1757. (c) Pemberton, N.; Chorell, E.; Almqvist, F. Top. Heterocycl. Chem. 2006, 1, 1. (d) Ciufolini, M. A.; Chan B. K. Heterocycles 2007, 74, 101.

2. A pioneer work on 2-pyridone derivatives as NNRTIs, (a) Goldman, M. E.; Nunberg, J. H.; O’Brien, J. A.; Quintero, J. C.; Schleif, W. A.; Freund, K. F.; Gaul, S. L.; Saari, W. S.; Wai, J. S.; Hoffman, J. M.; Anderson, P. S.; Hupe, D. J.; Emini, E. A.; Stern, A. M. Proc. Natl. Acad. Sci. USA. 1991, 88, 6863. For recent review, see: (b) Medina-Franco, J. L.; MartínezMayorga, K.; Juárez-Gordiano, C.; Castillo, R. Chem. Med. Chem. 2007, 2, 1141.

3. For review, see: (a) Li, Q.; Mitscher, L. A.; Shen, L. L. Med. Res. Rev. 2000, 20, 231. (b) Holzgrabe, U. Pharm. Unserer Zeit. 2001, 30, 446.

4. Gupta, A. K.; Plott, T. Int. J. Dermatol. 2004, 43 (Suppl.1), 3.

5. Fo review, see: (a) Endoh, M.; Hori, M. Exp. Opin. Pharmacother. 2006, 7, 2179. Selected articles: (b) Robert, N.; Verrier, C.; Hoarau, C.; Celanire, S.; Marsais, F. Arkivoc. 2008, (vii), 92. (c) Presti, E. L.; Boggia, R.; Feltrin, A.; Menozzi, G.; Dorigo, P.; Mosti, L. Il Farmaco. 1999, $54,465$.

6. Sollogoub, M.; Fox, K. R.; Powers, V. E. C.; Brown, T. Tetrahedron Lett. 2002, 43, 3121. (b) Seidel, A.; Brunner, S.; Seidel, P.; Fritz, G. I.; Herbarth, O. British J. Cancer. 2006, 94, 1726. (c) Sun, Z.; Ahmed, S.; McLaughlin, L. W. J. Org. Chem. 2006, 71, 2922. (d) Yang, Z.; Hutter, D.; Sheng, P.; Sismour, A. M.; Benner, S. A. Nucl. Acids Res. 2006, 34, 6095. (e) Rajeswaran, M.; Srikrishnan, T. Nucleosides, Nucleotides and Nucleic Acids. 2008, 27, 1113.

7. Parsons, S.; Winpenny, R. E. P. Acc. Chem. Res. 1997, 30, 89.

8. Dyachenko, V. D.; Tkachev, R. P. Russ. J. Org. Chem. 2003, 39, 1174. Translated from Zh. Org. Khim. 2003, 39, 1245. (b) Tkachev, R. P.; Bityukova, O. S.; Dyachenko, V. D.; Tkacheva, V. P.; Dyachenko, A. D. Russ. J. Gen. Chem. 2007, 77, 116. Translated from Zh. Obshch. Khim. 2007, 77, 125. (c) Dzhavakhishvili, S. G.; Gorobets, N. Yu.; Chernenko, V. N.; Musatov, V. I; Desenko, S. M. Russ. Chem. Bull. Int. Ed. 2008, 57, 422. Translated from Izv. Akad. Nauk (Ser. Khim.). 2008, 412. (d) Gorobets, N. Yu.; Sedash, Yu. V.; Shishkina, S. V.; Shishkin, O. V.; Yermolayev, S. A.; Desenko, S. M. Arkivoc. 2009, (xiii), 23.

9. For a recent review on chemistry of N-substituted cyanoacetamides, see: Dyachenko, V. D.; Tkachiov, R. P.; Bityukova, O. S. Russ. J. Org. Chem. 2008, 44, 1565. Translated from Zh. Org. Khim. 2008, 44, 1591. 
10. Gorobets, N. Yu.; Yousefi, B. H.; Belaj, F.; Kappe, C. O. Tetrahedron. 2004, 60, 8633.

11. Yermolayev, S. A.; Gorobets, N. Yu.; Desenko S. M. J. Comb. Chem. 2009, 11, 44.

12. The use of functionalized alkoxyethylenes (including DEEMM) in heterocyclic chemistry (reviews): (a) Dyachenko, V. D.; Tkachev, R. P. Russ. J. Org. Chem. 2003, 39, 757. Translated from Zh. Org. Khim. 2003, 39, 807. (b) Dyachenko, V. D.; Tkachev, R. P. Russ. J. Org. Chem. 2006, 42, 149. Translated from Zh. Org. Khim. 2006, 42, 167.

13. Selvi, S.; Perumal, P. T. Org. Prep. Proc. Int. 2001, 33, 194. (b) Yogavel, M.; Aravindan, P. G.; Velmurugan, D.; Sekar, K.; Selvi, S.; Perumal, P. T.; Rajd, S. S.; Fune, H.-K. Acta Cryst. 2003, C59, o394.

14. Dawood, K. M.; Farag, A. M.; Khedr, N. A. Arkivoc. 2008, (xv), 166.

15. Granik, V. G.; Ershov, L. V.; Grizik, S. I.; Chistyakov, V. V. Chem. Heterocl. Comp. 1984. 20, 1026. Translated from Khim. Geterotsikl. Soed. 1984. 20, 1252.

16. Sheldrick G.M., SHELXS97. Program for the Solution of Crystal Structure, University of Göttingen, Germany, 1997.

17. Sheldrick G.M. SHELXL97. Program for the Refinement of crystal Structures, University of Göttingen, Göttingen, Germany. 